\title{
Effects of Extraction Techniques on Total Phenolic Content and Antioxidant Capacities of Two Oregano Leaves
}

\author{
Ahmad Karimi ${ }^{1}$, Byungjick Min ${ }^{2}$, Cindi Brownmiller ${ }^{2} \&$ Sun-Ok Lee ${ }^{2}$ \\ ${ }^{1}$ Animal Science Department, University of Kurdistan, Sanandaj, Kurdistan, Iran \\ ${ }^{2}$ Department of Food Science, University of Arkansas, Fayetteville, AR, 72704, United States \\ Correspondence: Sun-Ok Lee, Department of Food Science, University of Arkansas, 2650 N Young Avenue, \\ Fayetteville, AR 72704, United States. Fax: 1-479-575-6936; Tel: 1-479-575-6921. E-mail: sunok@uark.edu
}

Received: July 17, 2014 Accepted: November 20, 2014 Online Published: December 2, 2014

doi:10.5539/jfr.v4n1p112 URL: http://dx.doi.org/10.5539/jfr.v4n1p112

\begin{abstract}
The effects of dried oregano leaves (Mediterranean and Mexican oregano) extracted using different extraction techniques, solvent types, and six different ratios of each solvent to distilled water on total phenolic (TP) content and antioxidant properties were examined. The Folin-Ciocalteu and 1,1-Diphenyl-2-picryl-hydrazyl (DPPH) assays were performed to assess the antioxidant capacity. The different species of oregano had a significant effect on TP content (107.6 vs. $34.5 \mathrm{mg} \mathrm{GAEg}^{-1}$ in Mexican vs. Mediterranean oregano, respectively) $(P<0.05)$. Comparing extraction techniques, the vortex procedure significantly increased the measured TP content compared to sonication or shaking $(P<0.05)$; however, its effectiveness was sample species and solvent type dependent. Solvent type also had a significant impact on TP content of extracts in decreasing order of acetone, methanol, ethanol, and water $(P<0.05)$. The solvent:water ratio on TP content of each extract was significant $(P<0.05)$; higher TP content was measured for 40:60 and 60:40 acetone:water ratios for Mediterranean and 60:40 and 80:20 acetone:water ratios for Mexican oregano. The antioxidant capacity had a strong relationship with total phenolic contents. The current findings indicated that the species, extraction techniques, solvent type and the ratio of solvent:water had a significance influence on the TP content of two different species of dried oregano leaf, which may be a possible reason behind most variability reported on TP compounds of herbal and medicinal plants.
\end{abstract}

Keywords: antioxidant capacity, mediterranean oregano, mexican oregano, total phenolic content

\section{Introduction}

Products from herbs, spices and medicinal plants have a potential health benefits (Nanasombat \& Lohasupthawee, 2005; Dadalioğlu \& Evrendilek, 2004; Suhaj, 2006; Yoshino et al., 2006; Amarowicz et al., 2009). A growing number of studies have been performed in order to evaluate their chemical profile, test their nutraceutical properties, identify their potent bioactive components, and explore their new applications and detection tools (Rodríguez-Meizoso et al., 2006; Lin, Mukhopadhyay, Robbins, \& Harnly, 2007; Dawidowicz \& Rado, 2010). Studies have been reported the characterization and identification of herbal/medicinal products, but there were high variability in chemical composition and antioxidant properties of these products (Huie, 2002; Dorman, Peltoketo, Hiltunen, \& Tikkanen, 2003). Most of this variability is related to plant characteristics and complicated genetic and environmental interactions (Dunford and Vazquez 2005; Figuérédo, Cabassu, Chalchat, \& Pasquier, 2005; Tanko, Carrier, Duan, \& Clausen, 2005; Azizi, Yan, Honermeier, 2009; Napoli, Curcuruto, \& Ruberto, 2009), but it is also related to the technical variation among different laboratories briefly named as post-harvest variability, such as sample preparation, extraction method, solvent type, and detection ability (Tanko et al., 2005).

Oregano is an important spice, with increasing demand in the USA, mainly imported from Turkey, Mexico and Greece (Dunford \& Vazquez, 2005). The most common oregano types currently used as spice and food processing are commonly known as Mediterranean and Mexican oregano, though their botanical and physical characteristics are substantiality different. Mediterranean oregano belongs to the Lamiaceae family (Capecka, Mareczek, \& Leja, 2005), while Mexican oregano originated from the Verbenaceae family (Avila-Soa, Maria, Alejandro, Jose, \& Guadalupe, 2010). Mexican oregano has a darker, stronger and more robust flavor compared to the Mediterranean oregano (Dunford \& Vazquez, 2005). While various studies investigated only essential oil 
composition (Russo, Galletti, Bocchini, \& Carnacini 1998; D'Antuono, Galletti, \& Bocchini, 2000 ; Dadalioğlu \& Evrendilek, 2004; Ozel \& Kaymaz, 2004; Figuérédo, Cabassu, Chalchat, \& Pasquier, 2006; Azizi et al., 2009; Bisht, Chanotiya, Rana, \& Semwal 2009) and antioxidant capacity of oregano (Cervato, Carabelli, Gervasio, Cittera, Cazzola, \& Cestaro, 2000; Exarchou, Nenadis, Tsimidou, Gerothanassis, Troganis, \& Boskou, 2002; Dorman et al., 2003; Kulisic, Radonic, Katalinic, \& Milos, 2004; Capecka et al., 2005; Shan, Cai, Sun, \& Corke 2005; A. Nurmi, T. Nurmi, Mursu, Hiltunen, \& Voutilainen, 2006; Amarowicz et al., 2009), less has been done to systematically investigate the impact of solvent type and extraction technique on bioactive components of oregano (Exarchou et al., 2002; Boydag, Kurkcuoglu, Ozek, \& Baser, 2003).

Determination of total phenolic content from plant extracts would be used as a suitable indirect index to estimate the antioxidant capacity and to investigate the effectiveness of different preparation methods (Shan et al., 2005). Especially compared to other testing methods (static headspace gas chromatography and $\beta$-carotene bleaching test), the DPPH assay is rapid, simple and independent of sample polarity, thus it can be applied for quick screening of extracts from samples for radical scavenging activity (Koleva, Van Beek, Linssen, Groot \& Evstatieva, 2002; Matsuura, Chiji, Asakawa, Amano, Yoshihara, \& Mizutani, 2003).

Since the polarity and less hazardous nature of the solvent is of utmost important in the extraction of bioactive compounds of herbal products (Tanko et al., 2005; Luthria, Mukhopadhyay, \& Kwansa, 2006; Tsimogiannis, Stavrakaki, \& Oreopoulou, 2006), the objectives of this study were to systematically investigate the effect of solvent type, solvent to water ratio, and extraction techniques (shaker, sonication, and vortex mixing) on total phenolic content of dried oregano leaves from two different species (Mediterranean vs. Mexican).

\section{Materials and Methods}

\subsection{Plant Material}

Two species of dried oregano leaf (known as Mediterranean, Origanum vulgare and Mexican, Lippia graveolens) were kindly provided by Newly Weds Foods Company (Springdale, AR, USA). Both samples were kept in air-tight plastic bags and stored at $4{ }^{\circ} \mathrm{C}$ until analysis. The relative percentage of volatile essential oil contents of both dried leaf oregano samples (Mediterranean vs. Mexican) were previously determined by gas chromatography (GC)/ mass spectrometry (MS) with head space analysis (Karimi et al., 2010).

\subsection{Chemical and Reagents}

All solvent types used in this experiment were HPLC grade and purchased from VWR Scientific Products Inc. (Fayetteville, AR, U.S.A.). Deionized water was prepared using a Millipore Milli-Q purification system (Millipore Corp., Bedford, Mass., U.S.A.). Folin-Ciocalteu reagent, gallic acid, DPPH (2,2-Diphenyl-1-picrylhydrazyl) and sodium carbonate for measurement of total phenol (TP) content were purchased from Sigma Chemical Co. (St. Louis, Mo., U.S.A.).

\subsection{Solvent type and Extraction Procedure}

Three solvent types (ethanol, methanol, and acetone) each with six different ratios to water (solvent:water; $0: 100,20: 80,40: 60,60: 40,80: 20,100: 0)$ were used as extraction solvent mixtures. Three types of extraction techniques were used for extracting TP content of samples including shaker, sonication and vortex.

Extractions of TP contents of oregano samples were carried out according to Luthria et al. (2006). $250 \mathrm{mg}$ of each oregano sample were measured and added to $10 \mathrm{~mL}$ of the relevant solvent mixture. For the shaker technique, vials were placed on a MaxQ 2000 model shaker (Thermo Scientific, Asheville, N.C., U.S.A.) for 30 $\mathrm{min}$ at the maximum speed of 10. For the sonication technique, vials were placed in a sonication bath (Bransonic 35100R-DTH, Branson Ultrasonic Co., Danbury, Conn., U.S.A.) at $40{ }^{\circ} \mathrm{C}$ for $30 \mathrm{~min}$. For the vortex technique, vials were vortex-mixed for two minutes (three times) using a vortex (VM 3000 Minivortexer, VWR Scientific Products Inc. (Fayetteville, Ark., U.S.A.). Following each extraction technique, the vials were centrifuged $(10,000 \times \mathrm{g})$ for $10 \mathrm{~min}(\mathrm{~J} 2-21$ Beckman Coulter, Brea Calif. U.S.A.). After transferring the supernatant into a 25 $\mathrm{mL}$ volumetric flask, the residues were resuspended with an additional $5 \mathrm{~mL}$ of relevant solvent mixture. After gently mixing, the vials were recentrifuged for additional $5 \mathrm{~min}$. The supernatant of both centrifuge stages combined together and the final volume of each flask were filled to $25 \mathrm{~mL}$ using the relevant solvent mixture. Extraction and analysis of each sample was performed on the same day. Each extraction procedure was carried out in triplicate.

\subsection{Total Phenolic Content Assay}

The total phenolic content of oregano extracts was measured using the Folin-Ciocalteu (FC) assay as described by Luthria et al. (2006) with minor modification and using gallic acid as the standard. Before total phenolic 
assay, each aliquot was filtered by filter paper. Then, $60 \mu \mathrm{L}$ of extract transferred into a test tube, followed by addition of $8.74 \mathrm{~mL}$ of distilled water. The tubes were vortex mixed for $20 \mathrm{~s}$ and $300 \mu \mathrm{L}$ of FC reagent was added. After an additional $20 \mathrm{~s}$ of vortex mixing, $900 \mu \mathrm{L}$ of filtered $200 \mathrm{gL}^{-1}$ of sodium carbonate solution was added. After another $20 \mathrm{~s}$ of vortex mixing and $2 \mathrm{~h}$ sitting in ambient temperature, the absorbance of reaction mixtures was measured at $760 \mathrm{~nm}$ using a spectrophotometer (DU 520, Beckman Coulter, Brea, Calif., U.S.A.). The TP content of each extracted mixture was calculated using gallic acid standard curve and results expressed in $\mathrm{mg}$ of gallic acid equivalent per gram $\left(\mathrm{mg} \mathrm{GAE}^{-1}\right)$ of dried oregano leaf samples.

\subsection{HPLC/ESI-MS Analysis of Flavonoids}

Oregano samples $(250 \mathrm{mg}$ ) were vortexed for $2 \mathrm{~min}$ with $10 \mathrm{~mL}$ of $60 \%$ acetone, repeated 3 times. The samples were centrifuged at $10,000 \mathrm{xg}$ for $10 \mathrm{~min}$, and supernatant was collected. The residue was washed with $5 \mathrm{ml}$ of $60 \%$ acetone, and centrifuged at 10,000xg for $5 \mathrm{~min}$. The supernatants were pooled. A portion of the extract ( 3 $\mathrm{mL}$ ) was flushed with nitrogen until dry and reconstituted with $1 \mathrm{~mL} 50 \%$ aqueous methanol. The concentrated extracts were passed through a $0.45 \mu \mathrm{m}$ PTFE syringe filter prior to HPLC analysis.

The flavonoids were separated using a Phenomenex (Torrance, CA) Aqua $5 \mu \mathrm{m} \mathrm{C18}(250 \times 4.6 \mathrm{~mm})$ column and a binary gradient of $2 \%$ acetic acid for mobile phase A and $0.5 \%$ acetic acid in water/acetonitrile $(1: 1 \mathrm{v} / \mathrm{v})$ for mobile phase $\mathrm{B}$ at a flow rate of $1.0 \mathrm{~mL} / \mathrm{min}$. The linear gradient was from 10 to $50 \% \mathrm{~B}$ from 0 to $40 \mathrm{~min}$, held at $50 \%$ B for $5 \mathrm{~min}$, from 50 to $100 \%$ B from 45 to $65 \mathrm{~min}$, held at $100 \%$ B for $5 \mathrm{~min}$, and from 100 to $10 \% \mathrm{~B}$ from 70 to 71 , held and $10 \%$ for $5 \mathrm{~min}$.

An analytical Hewlett Packard 1100 series HPLC instrument equipped with an autosampler, a binary HPLC pump and a UV/VIS detector was used. Reverse phase separations of flavonoids were performed using the same HPLC conditions as described above, with absorption at $280 \mathrm{~nm}$ recorded for flavonols. For HPLC/MS analysis the HPLC apparatus was interfaced to a Bruker Esquire LC/MS ion trap mass spectrometer. Mass spectral data were collected with the Bruker software, which also controlled the instrument and collected the signal at 200 to $400 \mathrm{~nm}$. Conditions for mass spectral analysis in negative ion electrospray mode for flavonols included a capillary voltage of $4000 \mathrm{~V}$, a nebulising pressure of $30.0 \mathrm{psi}$, a drying gas flow of $9.0 \mathrm{~mL} \mathrm{~min}^{-1}$ and a temperature of $300^{\circ} \mathrm{C}$. Data were collected in full scan mode over a mass range of $m / z 200-1000$ at $1.0 \mathrm{~s}$ per cycle. Characteristic ions were used for peak assignment. For compounds where chemical standards were commercially available, retention times were also used to confirm the identification of components.

\subsection{DPPH Radical-Scavenging Assay}

The DPPH radical scavenging assay was conducted with minor modifications, according to previous study (Loizzo et al., 2010). The extracts $(0.5 \mathrm{~mL})$ were added to $0.5 \mathrm{~mL}$ of a $0.004 \%(\mathrm{w} / \mathrm{v})$ freshly made ethanol solution of DPPH. The mixture was mixed vigorously using a vortex and left to stand in ambient temperature in darkness for $20 \mathrm{~min}$, then the absorbance was measured at $517 \mathrm{~nm}$ using a spectrophotometer. Inhibition of free radical DPPH in percent was calculated by the formula:

$$
\text { Scavenging effect }(\%)=\left(\mathrm{A}_{\text {blank }}-\mathrm{A}_{\text {sample }} / \mathrm{A}_{\text {blank }}\right) \times 100
$$

Where $A_{\text {blank }}$ is absorbance of control (containing all reagents, except the sample) and $A_{\text {sample }}$ is the absorbance of the each sample. All experiments were run in triplicate.

\subsection{Statistical Analysis}

Experimental data were analyzed according to General Linear Model (GLM) procedure of SAS 9.4 (SAS institute, Cary, N.C., U.S.A.). Significant differences among treatments were determined by analysis of variance (ANOVA). An $\alpha$ of 0.05 was used to determine statistically significant differences.

\section{Results and Discussion}

There have been increasing interests in oregano as natural oxidant for human health and thus lots of studies have been conducted to determine potential health effects of oregano (Yoshino et al., 2006; Avila-Sosa et al., 2010; Chun, Vattem, Lin, \& Shetty, 2005). Moreover, extracts from oregano have not only natural antioxidants, but also antimicrobial activity and antifungal activity (Govaris, Solomakos, Pexara, \& Chatzopoulou, 2010; Portillo-Ruiz, Viramontes-Ramos, Munoz-Castellanos, Gastelum-Franco, \& Nevarez-Moorillon, 2005). The optimal extraction conditions for oregano samples are important because the health-promoting properties are determined by the biological evaluation of these extracts.

Figure 1 shows that the origin of dried oregano samples and extraction techniques had a significant influence on TP content of extract $(P<0.05)$. Average TP content of Mexican origin samples $(107.6 \pm 2.8 \mathrm{mg} / \mathrm{GAE})$ and 
Mediterranean samples $(34.5 \pm 1.24 \mathrm{mg} / \mathrm{GAE})$ was determined. This result indicates that the vortex is most efficient technique to extract phenolic compounds from both types of oregano.

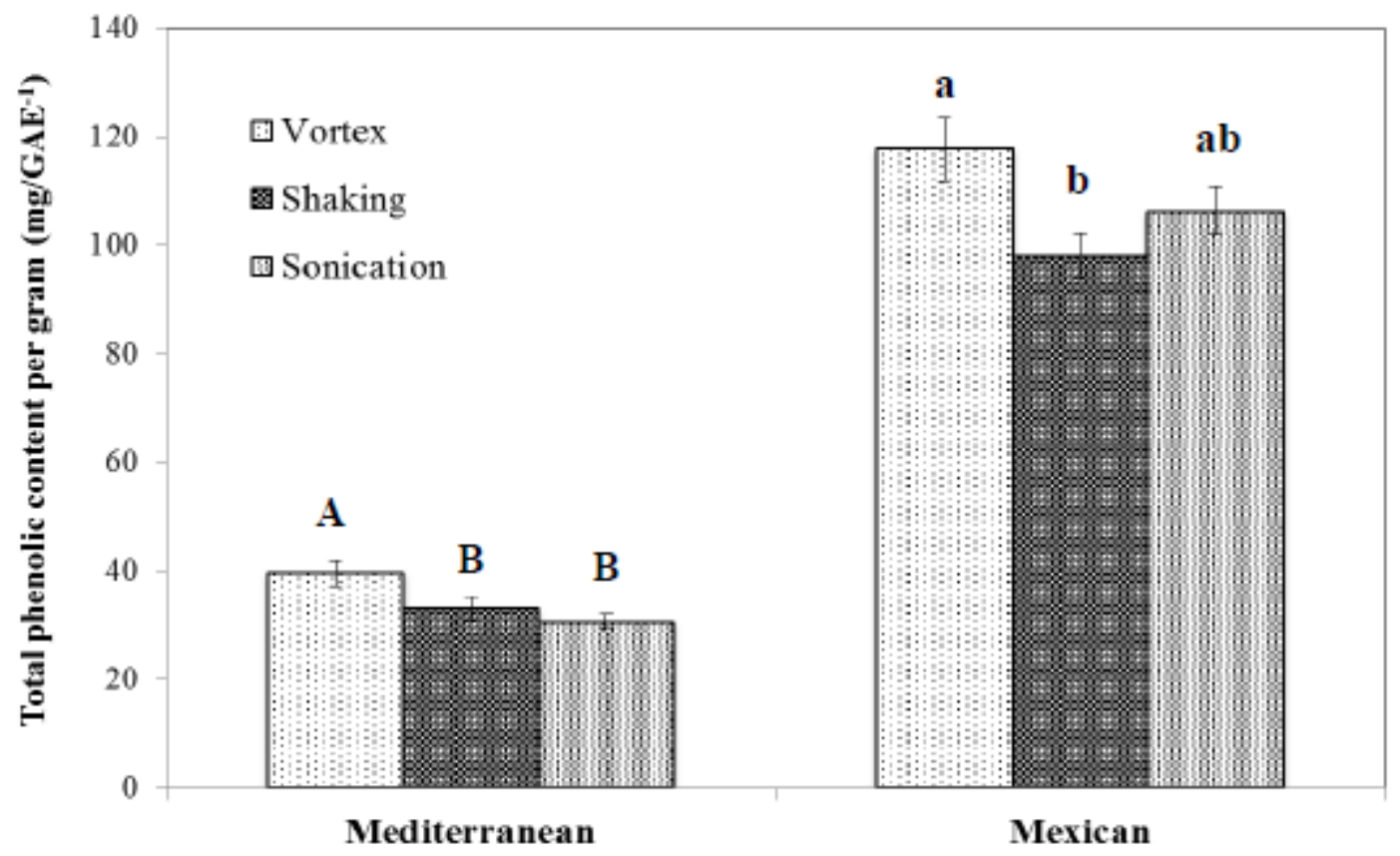

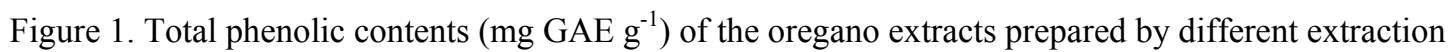
techniques. Different capital letters indicate significant differences among Mediterranean oregano $(\mathrm{P}<0.05)$.

Different lower-case letters indicate significant differences among Mexican oregano $(\mathrm{P}<0.05)$

In order to measure the antioxidant capacity of the samples, usually two or more methods are used because extracts might have different chemical characteristics (such as polarity) that might affect results of antioxidant assays. However, some studies (Matsuura et al., 2003; Kulisic et al., 2004; Puertas-Mejía, Hillebrand, Stashenko, \& Winterhalter, 2002) were already conducted using the DPPH assay and found no significant differences between methods such as $\beta$-carotene bleaching test, thiobarbituric acid reactive test, and the ABTS (radical monocation 2,2'-azino-bis (3-ethylbenzothiazoline-6-sulphonic acid)) method. Therefore this experiment used the DPPH assay was used to evaluate the antioxidant properties of oregano samples with different extraction methods. Figure 2 shows the scavenging effect of samples with different origins and extraction techniques. When a sample has greater phenolic content (Figure 1), it shows higher antioxidant properties. The vortex technique is the most efficient way to extract a fraction with the most potent antioxidant properties. Considering time and efficiency, vortexing is the most efficient technique of extraction. 


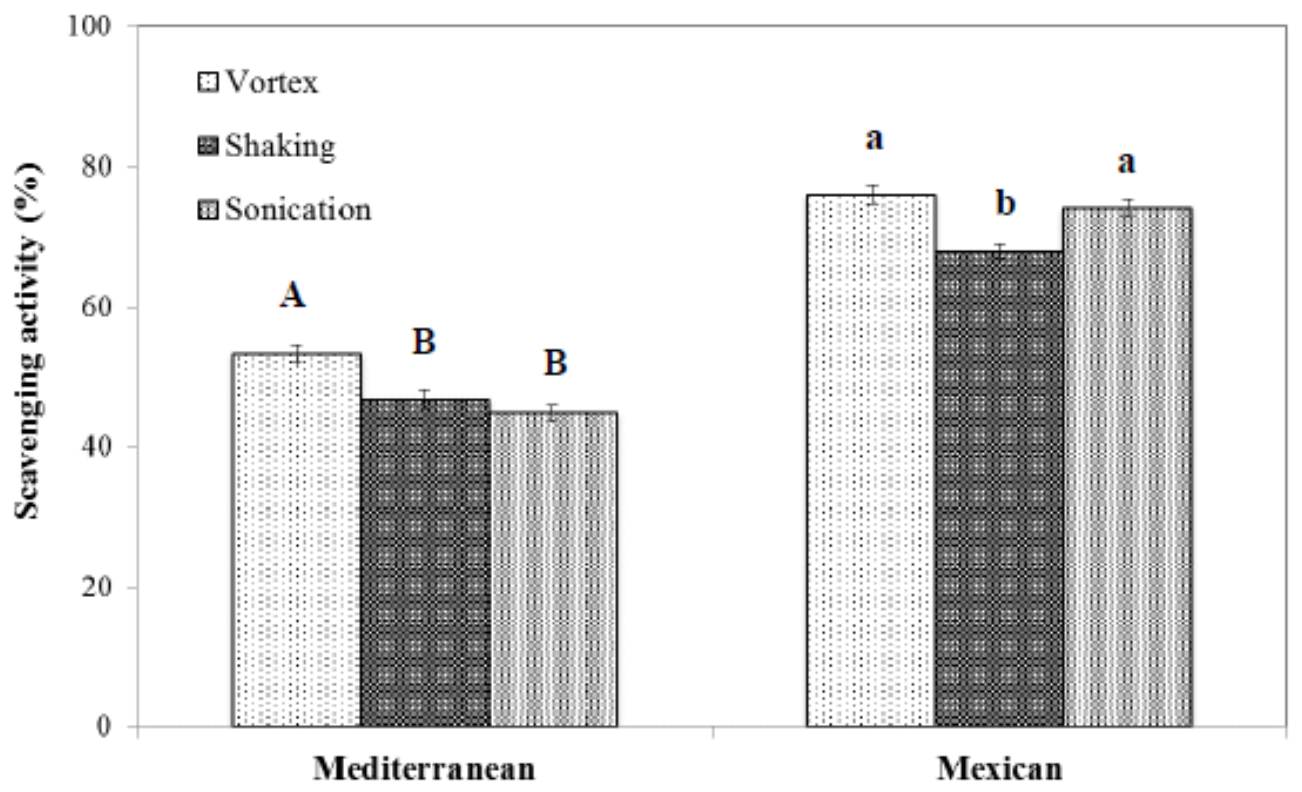

Figure 2. Scavenging activity (\%) of the oregano extracts prepared by different extraction techniques. Different capital letters indicate significant differences among Mediterranean oregano $(\mathrm{P}<0.05)$. Different lower-case letters indicate significant differences among Mexican oregano $(\mathrm{P}<0.05)$

Solvent type also had significant influences on total phenolic content and antioxidant capacities of samples (Table 1 and 2) $(P<0.05)$. Water was the least efficient solvent for extracting phenolic compounds from oregano samples. Extraction of oregano samples with organic solvents yield higher TP content and greater scavenging activity. Babili et al. (2011) reported that a decoction (water extraction with heat treatment) showed a lower amount of TP content than organic solvent extraction (ethanol, petroleum ether, ethyl acetate). In this study, extraction with acetone showed significantly higher phenolic compounds and antioxidant properties among treatments $(P<0.05)$.

Table 1. Total phenolic extraction ( $\mathrm{mg} \mathrm{GAE} \mathrm{g}^{-1}$ ) of the analyzed dried oregano samples

\begin{tabular}{ccc}
\hline Solvent Type & \multicolumn{2}{c}{ Total Phenolic Content $\left(\mathrm{mg} \mathrm{GAE} \mathrm{g}^{-1}\right)$} \\
& Mediterranean & Mexican \\
\hline Acetone & $39.6 \pm 2.9^{\mathrm{A}}$ & $118.77 \pm 6.6^{\mathrm{a}}$ \\
Methanol & $33.3 \pm 2.9^{\mathrm{AB}}$ & $113.43 \pm 2.9^{\mathrm{ab}}$ \\
Ethanol & $33.2 \pm 2.0^{\mathrm{AB}}$ & $102.6 \pm 3.7^{\mathrm{b}}$ \\
Water & $20.6 \pm 3.1^{\mathrm{C}}$ & $47.7 \pm 0.5^{\mathrm{c}}$ \\
\hline
\end{tabular}

Values are represented as Mean \pm SD of three replicates. Different capital letters indicate significant differences among Mediterranean oregano $(\mathrm{P}<0.05)$. Different lower-case letters indicate significant differences among Mexican oregano $(\mathrm{P}<0.05)$. 
Table 2. Scavenging activity (\%) of the analyzed dried oregano leaf samples

\begin{tabular}{ccc}
\hline \multirow{2}{*}{ Solvent Type } & \multicolumn{2}{c}{ Scavenging activity (\%) } \\
& Mediterranean & Mexican \\
\hline Acetone & $52.4 \pm 0.9^{\mathrm{A}}$ & $77.3 \pm 0.9^{\mathrm{a}}$ \\
Methanol & $48.2 \pm 0.8^{\mathrm{AB}}$ & $74.5 \pm 0.8^{\mathrm{b}}$ \\
Ethanol & $47.6 \pm 1.7^{\mathrm{AB}}$ & $72.0 \pm 0.7^{\mathrm{c}}$ \\
Water & $31.7 \pm 0.2^{\mathrm{C}}$ & $45.8 \pm 0.4^{\mathrm{d}}$ \\
\hline
\end{tabular}

Values are represented as Mean \pm SD of three replicates. Different capital letters indicate significant differences among Mediterranean oregano $(\mathrm{P}<0.05)$. Different lower-case letters indicate significant differences among Mexican oregano $(\mathrm{P}<0.05)$.

Based on current results, using a vortex and acetone is the most efficient technique of extracting phenolic compounds from oreganos. In order to determine highest yielding solvent ratio, 6 different solvent ratios were analyzed $(0 \%, 20 \%, 40 \%, 60 \%, 80 \%$, and $100 \%$ of each solvent). Results are shown in Figure 3 . For Mediterranean oregano, extraction with a 40:60 and 60:40 (acetone:water) ratio exhibited significantly higher TP content than other ratios $(P<0.05)$. Also, extraction with Mexican oregano showed that a 60:40 and 80:20 (acetone:water) ratio showed significantly more TP content. Antioxidant properties of extracts were determined (Figure 4). For Mediterranean oregano, extraction with a 40:60 and 60:40 (acetone:water) ratio were displayed significantly higher scavenging activity than other ratios $(P<0.05)$. Extractions of Mexican oregano show that a 80:20 and 60:40 (acetone:water) ratio exhibited significantly higher scavenging activity than other ratios $(P<0.05)$.

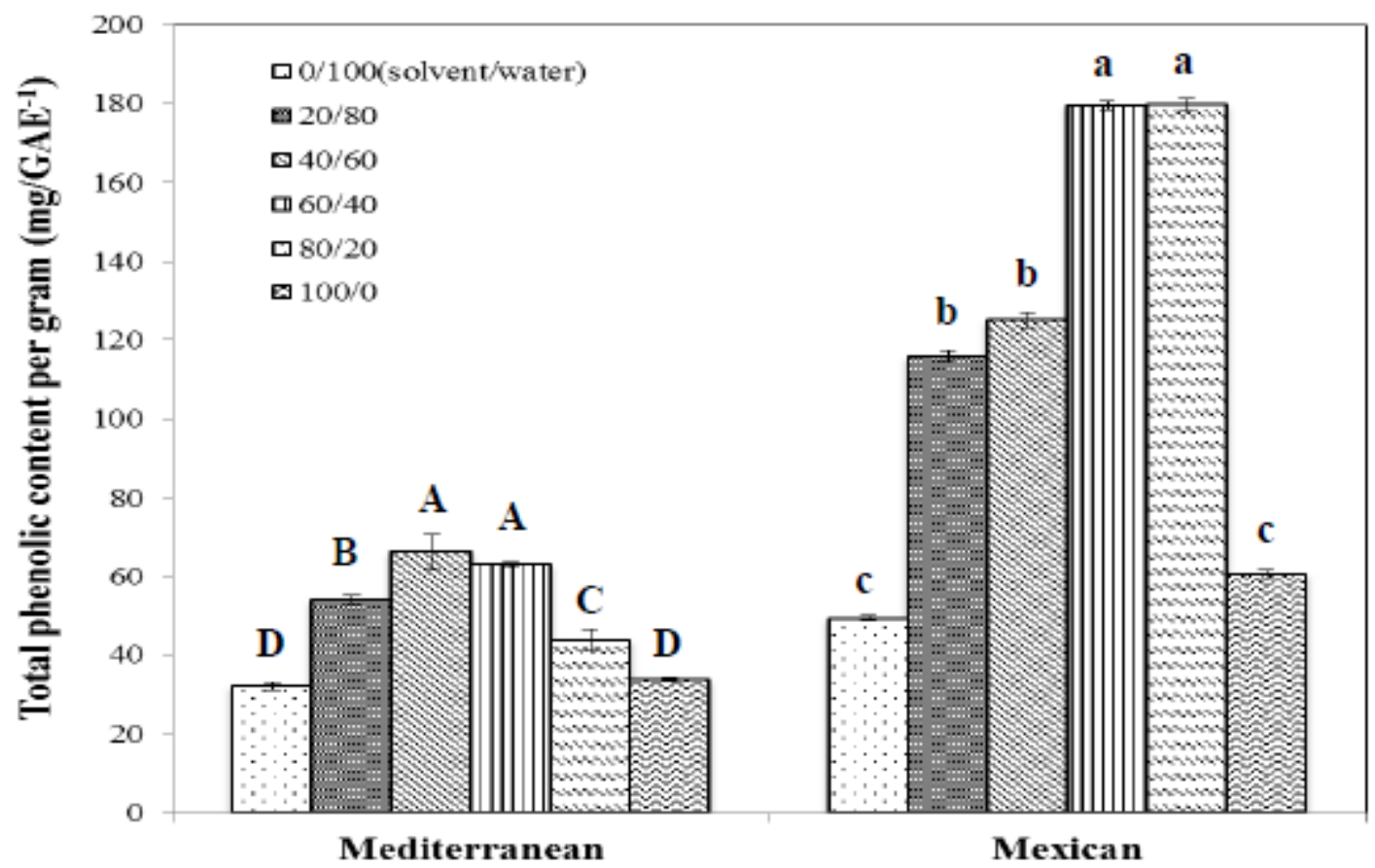

Figure 3. Total phenolic content ( $\mathrm{mg} \mathrm{GAE}^{-1}$ ) of the oregano extracts prepared by different acetone:water ratios using the vortexing technique. Different capital letters indicate significant differences among Mediterranean oregano $(\mathrm{P}<0.05)$. Different lower-case letters indicate significant differences among Mexican oregano $(\mathrm{P}<0.05)$ 


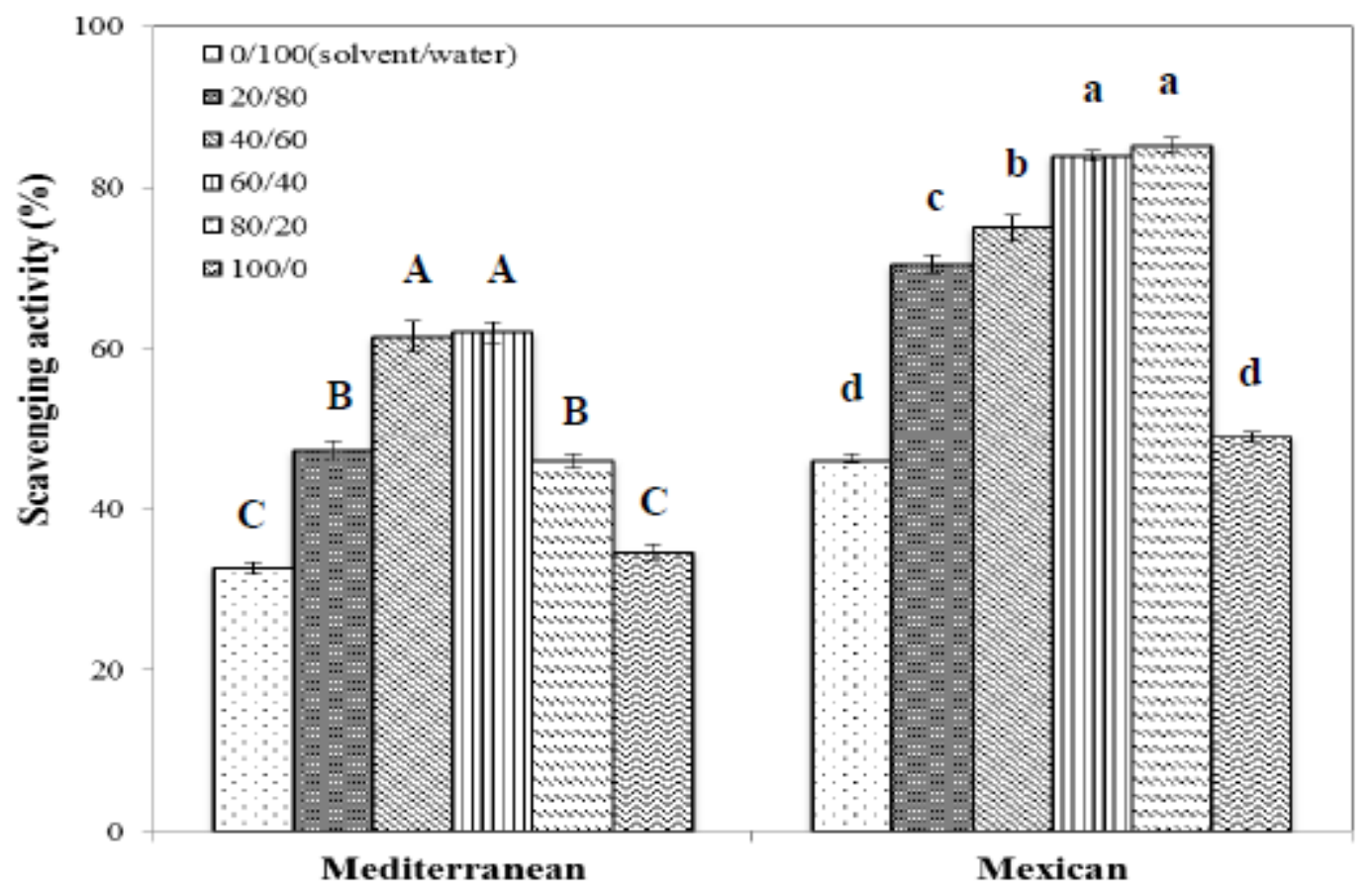

Figure 4. Scavenging activity (\%) of the oregano extracts prepared by different acetione:water ratios using the vortexing technique. Different capital letters indicate significant differences among Mediterranean oregano $(\mathrm{P}<0.05)$. Different lower-case letters indicate significant differences among Mexican oregano $(\mathrm{P}<0.05)$

Figure 5 showed the HPLC chromatograms and concentrations of flavonoids in Mediterranean and Mexican oreganos. Each peak number represented the identification and concentration of flavonoids in both oreganos. Total concentrations of flavonoids in Mexican and Mediterranean were 8274.4 $\pm 76.8 \mathrm{mg}$ and 4197.3+160.2 $\mathrm{mg} / 100 \mathrm{~g}$, respectively. These results indicate that even Mediterranean and Mexican oregano extracted by method using acetone and vortex shows greater antioxidant activities over the other methods analyzed, but the ideal solvent for each sample ratio is different. 

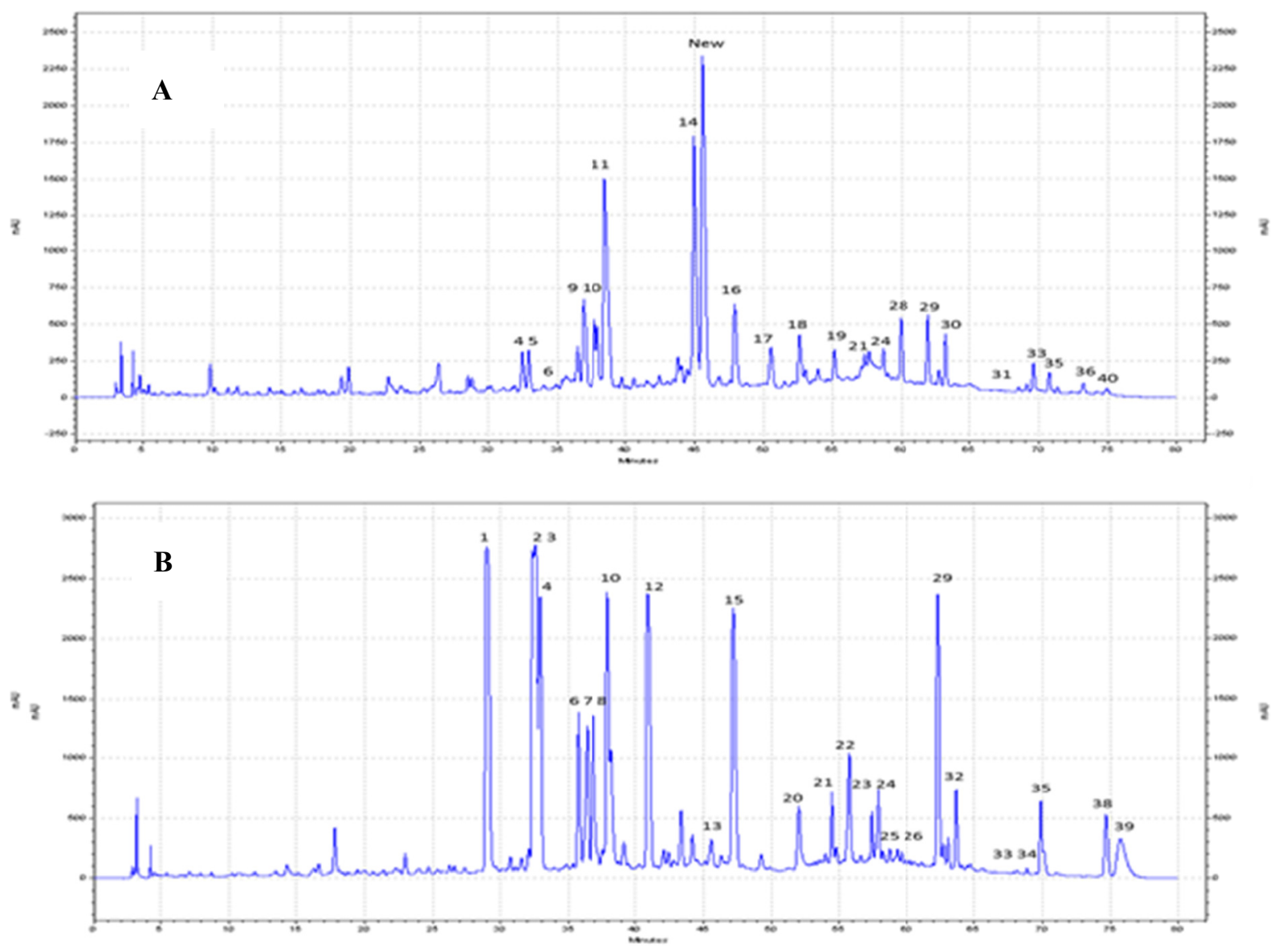

Figure 5. Typical high-performance liquid chromatogram of flavonoids in Mediterranean (A) and Mexican (B) oreganos. Peak number represents the identification and concentrations of flavonoids in both oreganos

\begin{tabular}{llll}
\hline $\begin{array}{c}\text { Peak number of } \\
\text { HPLC chromatogram }\end{array}$ & \multicolumn{1}{c}{ Identification } & $\begin{array}{c}\text { Mexican Oregano } \\
(\mathbf{m g} / \mathbf{1 0 0 g})\end{array}$ & \multicolumn{1}{c}{$\begin{array}{c}\text { Mediterranean } \\
\text { Oregano (mg/100g) }\end{array}$} \\
\hline 1 & Pentahydroxyflavanone-A-Hexoside $^{\mathrm{a}}$ & $927.5 \pm 8.8$ & $\mathrm{ND}$ \\
\hline 2 & Pentahydroxyflavanone-B-Hexoside $^{\mathrm{a}}$ & $444.3 \pm 29.8$ & $\mathrm{ND}$ \\
\hline 3 & Pentahydroxyflavanone-B-Hexoside $^{\mathrm{a}}$ & $642.1 \pm 80$ & $\mathrm{ND}$ \\
\hline 4 & Quercetin 3-O-galactoside $^{\mathrm{b}}$ & $599.3 \pm 10.6$ & $57.1 \pm 0.9$ \\
\hline 5 & Quercetin 3-O-glucoside $^{\mathrm{b}}$ & $550.2 \pm 20.1$ & $288.0 \pm 5.4$ \\
\hline 6 & Taxifolin $^{\mathrm{c}}$ & $927.5 \pm 8.8$ & $47.5 \pm 4.4$ \\
\hline 7 & Unknown $^{\mathrm{a}}$ & $53.0 \pm 3.3$ & $\mathrm{ND}$ \\
\hline 8 & Unknown $^{\mathrm{a}}$ & $310.6 .0 \pm 10.8$ & $\mathrm{ND}$ \\
\hline 9 & Unknown $^{\mathrm{a}}$ & $\mathrm{ND}$ & $73.6 \pm 8$ \\
\hline 10 & Luteolin 7-O-glucoside $^{\mathrm{c}}$ & $736.3 \pm 6.9$ & $118.8 \pm 4.6$ \\
\hline 11 & Unknown $^{\mathrm{a}}$ & $\mathrm{ND}$ & $454.2 \pm 37.3$ \\
\hline 12 & 3-Hydroxyphloretin & $265.7 \pm 8.8$ & $\mathrm{ND}$ \\
\hline 13 & $6^{\prime}-O-r h a m n o s i d \mathrm{~d}^{\mathrm{d}}$ & & $\mathrm{ND}$ \\
\hline 14 & 6-Hydroxyluteolin & \\
\hline
\end{tabular}




\begin{tabular}{|c|c|c|c|}
\hline New & Luteolin-glucuronide & ND & $420.6 \pm 52.6$ \\
\hline 15 & Phloridzin $^{\mathrm{c}}$ & $808.8 \pm 21.4$ & ND \\
\hline 16 & Unknown $^{\text {a }}$ & ND & $149.6 \pm 9.1$ \\
\hline 17 & Unknown $^{\mathrm{a}}$ & ND & $95.7 \pm 19.8$ \\
\hline 18 & Unknown $^{\mathrm{a}}$ & ND & $102.0 \pm 7.4$ \\
\hline 19 & Unknown $^{a}$ & ND & $96.7 \pm 7.6$ \\
\hline 20 & Unknown $^{\mathrm{a}}$ & $356.4 .0 \pm 12.1$ & ND \\
\hline 21 & Eriodictyol $^{\mathrm{a}}$ & $671.2 \pm 18.9$ & $93.3 \pm 14$ \\
\hline 22 & Unknown $^{\mathrm{a}}$ & $137.4 .0 \pm 5.3$ & ND \\
\hline 23 & Quercetin $^{b}$ & $163.6 \pm 4.9$ & ND \\
\hline 24 & Luteolin $^{\mathrm{a}}$ & $320.6 \pm 9.7$ & $94.6 \pm 6.1$ \\
\hline 25 & Unknown $^{\mathrm{a}}$ & $175.9 .0 \pm 33.4$ & ND \\
\hline 26 & Unknown $^{\mathrm{a}}$ & $125.0 \pm 15$ & ND \\
\hline 27 & Luteolin-7-O-rutinoside $^{\mathrm{a}}$ & ND & ND \\
\hline 28 & Unknown $^{\mathrm{a}}$ & ND & $137.2 \pm 8.7$ \\
\hline 29 & Naringenin $^{c}$ & $620.9 \pm 2.9$ & $151.1 \pm 15.1$ \\
\hline 30 & Unknown $^{\mathrm{a}}$ & ND & $78.2 \pm 17.1$ \\
\hline 31 & Apigenin $^{c}$ & ND & $77.2 \pm 6.6$ \\
\hline 32 & 6-Methylscutellarein ${ }^{\mathrm{a}}$ & $164.1 \pm 7.6$ & ND \\
\hline 33 & Unknown $^{\text {a }}$ & $180.8 .0 \pm 2.4$ & $40.4 \pm 1.7$ \\
\hline 34 & Unknown $^{\mathrm{a}}$ & $122.2 .0 \pm 5.2$ & ND \\
\hline 35 & 6,7-Dimethylscutellarein ${ }^{\mathrm{a}}$ & ND & $22.3 \pm 0.3$ \\
\hline 36 & Unknown $^{\text {a }}$ & ND & $32.9 \pm 3.3$ \\
\hline 37 & Sakuranetin $^{\mathrm{a}}$ & ND & ND \\
\hline 38 & Pinocembrin $^{c}$ & $215.3 \pm 6.8$ & ND \\
\hline 39 & Galangin $^{c}$ & $302.1 \pm 23.6$ & ND \\
\hline 40 & Methylgalangin $^{\mathrm{e}}$ & ND & $35.4 \pm 5.1$ \\
\hline 41 & Unknown $^{\mathrm{a}}$ & $62.1 .0 \pm 4.8$ & ND \\
\hline Total & & $8274.4 .0 \pm 76.8$ & $4197.3 \pm 160.2$ \\
\hline
\end{tabular}

${ }^{a}$ Values are expressed as luteolin equivalents, ${ }^{b}$ expressed as quercetin equivalents, ${ }^{c}$ quantified based on linear regression of respective known compounds, ${ }^{\mathrm{d}}$ expressed as phloridzin equivalents, expressed as galangin equivalents. $\mathrm{ND}=$ not detected.

\section{Conclusion}

The significant impact of solvent:water ratio, and its solvent and sample origin dependency on total phenol content emphasize that the selection of the appropriate solvent type or ratio is an important task. In conclusion, the finding of the present experiment clearly showed that the origin of oregano sample, solvent type, and solvent:water ratios are all important factors influencing the measured total phenol content. It is evident that the most efficient extraction method for both oregano samples is using a vortex with acetone, but showing different solvent ratio for maximum TP content: Mediterranean is 40:60 and 60:40, while Mexican is 60:80 and 80:20 (acetone:water). 


\section{Acknowledgements}

This work was supported by the National Science Foundation-EPSCoR (Center for Plant-Powered Production) at the University of Arkansas.

\section{References}

Amarowicz, R., Żegarska, Z., Rafalowski, R., Pegg, R. B., Karamać, M., \& Kosińska, A. (2009). Antioxidant activity and free radical- scavenging capacity of ethanolic extracts of thyme, oregano, and marjoram. Eur J Lipid Sci Technol, 111, 1111-1117. http://dx.doi.org/ 10.1002/ejlt.200800170

Avila-Sosa, R., María, G. G. F., Alejandro, C. D., José, V. T. M., \& Guadalupe, V. N. M. (2010). Extracts of Mexican oregano (Lippia berlandieri Schauer) with antioxidant and antimicrobial activity. Food Bioprocess Tech, 3, 434-440. http://dx.doi.org/10.1007/s11947-008-0085-7

Azizi, A., Yan, F., \& Honermeier, B. (2009). Herbage yield, essential oil content and composition of three oregano (Origanum vulgare L.) populations as affected by soil moisture regimes and nitrogen supply. Ind Crop Prod, 29, 554-561. http://dx.doi.org/10.1016/j.indcrop.2008.11.001

Babili, F. E., Bouajila, J., Souchard, J. P., Bertrand, C., Bellvert, F., Fouraste, I., \& Valentin, A. (2011). Oregano: chemical analysis and evaluation of its antimalarial, antioxidant, and cytotoxic activities. $J$ Food Sci, 76(3), C512-C518. http://dx.doi.org/10.1111/j.1750-3841.2011.02109.x

Bisht, D., Chanotiya, C. S., Rana, M., \& Semwal, M. (2009). Variability in essential oil and bioactive chiral monoterpenoid compositions of Indian oregano (Origanum vulgare L.) populations from northwestern Himalaya and their chemotaxonomy. Ind Crop Prod, 30, 422-426. http://dx.doi.org/10.1016/j.indcrop.2009.07.014

Boydag, I., Kurkcuoglu, M., Ozek, T., \& Baser, K. H. C. (2003). Isolation of some soluble and dispersed materials of oregano water. Chem Nat Compd, 39(5), 465-469. http://dx.doi.org/10.1023/B:CONC.0000011121.37689.65

Capecka, E., Mareczek, A., \& Leja, M. (2005). Antioxidant activity of fresh and dry herbs of some Lamiaceae species. Food Chem, 93, 223-226. http://dx.doi.org/10.1016/j.foodchem.2004.09.020

Cervato, G., Carabelli, M., Gervasio, S., Cittera, A., Cazzola, R., \& Cestaro, B. (2000). Antioxidant properties of oregano (Origanum vulgare) leaf extracts. $J$ Food Biochem, 24, 453-465. http://dx.doi.org/10.1111/j.1745-4514.2000.tb00715.x

Chun, S. S., Vattem, D. A., Lin, Y. T., \& Shetty, K. (2005). Phenolic antioxidants from clonal oregano Origanum vulgare with antimicrobial activity against Helicobacter pylori. Process Biochem, 40, 809-816. http://dx.doi.org/10.1016/j.procbio.2004.02.018

D'Antuono, L. F., Galletti, G. C., \& Bocchini, P. (2000). Variability of essential oil content and composition of Origanum vulgare L. populations from a North Mediterranean area (Liguria region, northern Italy). Ann Bot-London, 86, 471-78. http://dx.doi.org/10.1006/anbo.2000.1205

Dadalioğlu, I., \& Evrendilek, G. A. (2004). Chemical compositions and antibacterial effects of essential oils of Turkish oregano (Origanum minutiflorum), bay laurel (Laurusnobilis), Spanish lavender (Lavandulastoechas L.), and fennel (Foeniculum vulgare) on common food borne pathogens. J Agric Food Chem, 52, 8255-8260. http://dx.doi.org/10.1021/jf049033e

Dawidowicz, A. L., \& Rado, E. (2010). Matrix solid-phase dispersion (MSPD) in chromatographic analysis of essential oils in herbs. J Pharmaceut Biomed, 52, 79-85. http://dx.doi.org/10.1016/j.jpba.2009.12.024

Dorman, H. J. D., Peltoketo, A., Hiltunen, R., \& Tikkanen, M. J. (2003). Characterisation of antioxidant properties of de-odourised aqueous extracts from selected lamiaceae herbs. Food Chem, 83, 255-262. http://dx.doi.org/10.1016/S0308-8146(03)00088-8

Dunford, N. T., \& Vazquez, R. S. (2005). Effect of water stress on plant growth and thymol and carvacrol concentrations in Mexican oregano growth under controlled conditions. J Appl Hortic, 7(1), 20-22.

Exarchou, V., Nenadis, N., Tsimidou, M., Gerothanassis, I. P., Troganis, A., \& Boskoum D. (2002). Antioxidant activities and phenolic composition of extracts from Greek oregano, Greek sage, and summer savory. $J$ Agric Food Chem, 50, 5294-5299. http://dx.doi.org/10.1021/jf020408a

Figuérédom, G., Cabassu, P., Chalchat, J., \& Pasquier, B. (2005). Studies of Mediterranean oregano populations. V- Chemical composition of essential oils of oregano: Origanum syriacumL. var. bevanii (Holmes) 
Ietswaart, $O$. syriacum L. var. sinaicum (Boiss.) Ietswaart, and $O$. syriacum L. Var. syriacumfrom Lebanon and Israel. Flavour Frag J, 20, 164-168. http://dx.doi.org/10.1002/ffj.1408

Figuérédo, G., Cabassu, P., Chalchat, J., \& Pasquier, B. (2006). Studies of Mediterranean oregano populations. VIII- Chemical composition of essential oils of oreganos of various origins. Flavour Frag J, 21, 134-139. http://dx.doi.org/10.1002/ffj.1543

Govaris, A., Solomakos, N., Pexara, A., \& Chatzopoulou, P. S. (2010). The antimicrobial effect of oregano essential oil, nisin and their combination against Salmonella Enteritidis in minced sheep meat during $\begin{array}{llllll}\text { refrigerated } \quad \text { storage. Int } J \text { Food } & \text { Microbiol, } & 137, & \text { 175-180. }\end{array}$ http://dx.doi.org/10.1016/j.ijfoodmicro.2009.12.017

Huie, C. W. (2002). A review of modern sample-preparation techniques for the extraction and analysis of medicinal plants. Anal Bioanal Chem, 373, 23-30. http://dx.doi.org/10.1007/s00216-002-1265-3

Karimi, A., Yan, F., Coto, C., Park, J. H., Min, Y., Lu, C., Gidden, J. A., Lay, Jr. J. O., \& Waldroup, P. W. (2010). Effects of level and source of oregano leaf in starter diets for broiler chicks. J Appl Poult Res, 19, 137-145. http://dx.doi.org/10.3382/japr.2009-00088

Koleva, I. I., Van Beek, T. A., Linssen, J. P., Groot, A. D., \& Evstatieva, L. N. (2002). Screening of plant extracts for antioxidant activity: a comparative study on three testing methods. Phytochem Analysis, 13(1), 8-17. http://dx.doi.org/10.1002/pca.611

Kulisic, T., Radonic, A., Katalinic, V., \& Milos, M. (2004). Use of different methods for testing antioxidative activity of oregano essential oil. Food Chem, 85, 633-640. http://dx.doi.org/10.1016/j.foodchem.2003.07.024

Lin, L. Z., Mukhopadhyay, S., Robbins, R. J., \& Harnly, J. M. (2007). Identification and quantification of flavonoids of Mexican oregano (Lippiagraveolens) by LC-DAD-ESI/MS analysis. $J$ Food Compos Anal, 20, 361-369. http://dx.doi.org/10.1016/j.jfca.2006.09.005

Luthria, D. L., Mukhopadhyay, S., \& Kwansa, A. L. (2006). A systematic approach for extraction of phenolic compounds using parsley (Petroselinumcrispm) flakes as a model substrate. J Sci Food Agri, 86, 1350-1358. http://dx.doi.org/10.1002/jsfa.2521

Loizzo, M. R., Tundis, R., Chandrika, U. G., Abeysekera, A. M., Menichini, F., \& Frega, N. G. (2010). Antioxidant and antibacterial activities on foodborne pathogens of Artocarpus heterophyllus Lam. (Moraceae) leaves extracts. J Food Sci, 75, M291-5. http://dx.doi.org/10.1111/j.1750-3841.2010.01614.x

Matsuura, H., Chiji, H., Asakawa, C., Amano, M., Yoshihara, T., \& Mizutani, J. (2003). DPPH radical scavengers from dried leaves of oregano (Origanum vulgare). Biosci Biotech Bioch, 67(11), 2311-2316. http://dx.doi.org/10.1271/bbb.67.2311

Nanasombat, S., \& Lohasupthawee, P. (2005). Antibacterial activity of crude ethanolic extracts and essential oils of spices against Salmonellae and other enterobacteria. Sci Tech J, 5(3), 527-538.

Napoli, E., Curcuruto, G., \& Ruberto, G. (2009). Screening the essential oil composition of wild Sicilian oregano. Biochem Syst Ecol, 37, 484-493. http://dx.doi.org/10.1016/j.bse.2009.07.008

Nurmi, A., Nurmi, T., Mursu, J., Hiltunen, R., \& Voutilainen, S. (2006). Ingestion of oregano extract increases excretion of urinary phenolic metabolites in humans. J Agric Food Chem, 54, 6916-6923. http://dx.doi.org/10.1021/jf060879n

Ozel, M. Z., \& Kaymaz, H. (2004). Superheated water extraction, steam distillation and soxhlet extraction of essential oils of Origanum onites. Anal Bioanal Chem, 379, 112-1133. http://dx.doi.org/10.1007/s00216-004-2671-5

Portillo-Ruiz, M. C., Viramontes-Ramos, S., Munoz-Castellanos, L. N., Gastelum-Franco, M. G., \& Nevarez-Moorillon, G. V. (2005). Antifungal activity of Mexican oregano (Lippia berlandieri Shauer). $J$ Food Protect, 68, 2713-2717.

Puertas-Mejía, M., Hillebrand, S., Stashenko, E., \& Winterhalter, P. (2002). In vitro radical scavenging activity of essential oils from Columbian plants and fractions from oregano (Origanum vulgare L.) essential oil. Flavour Frag J, 17(5), 380-384. http://dx.doi.org/10.1002/ffj.1110

Rodríguez-Meizoso, I., Marin, F. R., Herrero, M., Seňorans, F. J., Reglero, G., Cifuentes, A., \& Ibáňez, E. (2006). Subcritical water extraction of nutraceuticals with antioxidant activity from oregano. Chemical and 
functional characterization. $J$ Pharmaceut $\quad$ Biomed, $1560-1565$. http://dx.doi.org/10.1016/j.jpba.2006.01.018

Russo, M., Galletti, G. C., Bocchini, P., \& Carnacini, A. (1998). Essential oil chemical composition of wild populations of Italian oregano spice (Origanum vulgare ssp. hirtum (Link) ietswaart): A preliminary evaluation of their use in chemotaxonomy by cluster analysis. 1. Inflorescences. J Agric Food Chem, 46, 3741-3746. http://dx.doi.org/10.1021/jf980087w

Shan, B., Cai, Y. Z., Sun, M., \& Corke, H. (2005). Antioxidant capacity of 26 spice extracts and characterization of their phenolic constituents. J Agric Food Chem, 53, 7749-7759. http://dx.doi.org/10.1021/jf051513y

Suhaj, M. (2006). Spice antioxidants isolation and their antiradical activity: a review. J Food Comp Anal, 19, 531-537. http://dx.doi.org/10.1016/j.jfca.2004.11.005

Tanko, H., Carrier, D. J., Duan, L., \& Clausen, E. (2005). Pre- and post-harvest processing of medicinal plants. Plant Gen Res, 3(2), 304-313. http://dx.doi.org/10.1079/PGR200569

Tsimogiannis, D., Stavrakaki, M., \& Oreopoulou, V. (2006). Isolation and characterization of antioxidant components from oregano (Origanum heracleoticum). Int $J$ Food Sci Tech, 41, 39-48. http://dx.doi.org/10.1111/j.1365-2621.2006.01259.x

Yoshino, K., Higashi, N., \& Koga, K. (2006). Antioxidant and anti-inflammatory activities of oregano extract. $J$ Health Sci, 52(2), 169- 173. http://dx.doi.org/10.1248/jhs.52.169

\section{Copyrights}

Copyright for this article is retained by the author(s), with first publication rights granted to the journal.

This is an open-access article distributed under the terms and conditions of the Creative Commons Attribution license (http://creativecommons.org/licenses/by/3.0/). 